University of Nebraska - Lincoln

DigitalCommons@University of Nebraska - Lincoln

Great Plains Wildlife Damage Control Workshop Wildlife Damage Management, Internet Center Proceedings

December 1975

\title{
A Live Trap for Birds Attending a Feeding Station
}

\author{
J.L. Hart \\ Department of Biological Sciences; Fort Hays Kansas State College, Hays, Kansas \\ L.L. Todd \\ Department of Biological Sciences; Fort Hays Kansas State College, Hays, Kansas
}

Follow this and additional works at: https://digitalcommons.unl.edu/gpwdcwp

Part of the Environmental Health and Protection Commons

Hart, J.L. and Todd, L.L., "A Live Trap for Birds Attending a Feeding Station" (1975). Great Plains Wildlife Damage Control Workshop Proceedings. 189.

https://digitalcommons.unl.edu/gpwdcwp/189

This Article is brought to you for free and open access by the Wildlife Damage Management, Internet Center for at DigitalCommons@University of Nebraska - Lincoln. It has been accepted for inclusion in Great Plains Wildlife Damage Control Workshop Proceedings by an authorized administrator of DigitalCommons@University of Nebraska - Lincoln. 


\title{
A LIVE TRAP FOR BIRDS ATTENDING A FEEDING STATION
}

\author{
J. L. Hart and L. L. Todd \\ Department of Biological Sciences \\ Fort Hays Kansas State College, Hays, Kansas 67601
}

\begin{abstract}
An effective live trap for capturing nuthatches, titmice, and woodpeckers was constructed from hail screen and modified mouse traps. Over 88 percent of active sets resulted in captures.
\end{abstract}

\section{INTRODUCTION}

The trap described herein was developed primarily to supplement the mist net in capturing nuthatches, titmice, and woodpeckers. These birds are easily attracted to feeding stations baited with suet and a baited trap, activated by the bird, is an effective method of capture. The trap is easily moved from one area to another, is relatively inexpensive to construct, and can be used in periods of inclement weather. Primary disadvantages are the time required for construction (about three hours) and the limitation of one capture per active set.

\section{CONSTRUCTION}

A $30 \times 36$ inch piece of $1 / 4$-inch mesh hail screen is used for each trap. This rectangular screen is trimmed by removing a $12 \times 12$ inch piece from each of the lower corners. This T-shaped piece of screen is then bent into a box shape with the back and top open. The seams of the joining sides and bottom are secured at 3-inch intervals by tying them with 1 ight gauage wire. An $8 \times 12$ inch rectangular frame is formed from heavy gauge clothesline wire and covered with one of the $12 \times 12$ inch pieces of screen remaining from the initial cutting. This serves as a top door for the trap and is hinged by inserting large nails through wooden hinges (Fig.la) into the wire mesh of the top door.

The trigger mechanism is constructed by adding a wire loop over the bail (Fig. $1 \mathrm{~g}$ ) of a Museum Special snap trap to restrict its movement to approximately one inch. It is then attached in an inverted position to an aluminum plate hinged midway on the front side of the trap (Fig. Id). This trigger plate is held perpendicular to the front of the trap by a small spring (Fig. le) gleaned from a discarded Sherman livetrap.

The hinged top door is connected to the trigger mechanism by an L-shaped piece of clothesline wire. A notch is filed in the distal end of this wire and hooked over the bail of the Museum Special on the trigger mechanism (Fig. If).

A $1 / 2 \times 1 \times 12$ inch piece of wood is added under the trigger mechanism, parallel to the front of the trap, and attached with wood screws through the sides of the trap. A 3-inch wood screw is inserted through a hole drilled slightly smaller than its diameter and which extends upwards toward the trigger of the inverted Museum Special (Fig. Ib).

To permit removal of captured birds, a small door is cut in the bottom of the trap. This is covered with the second $12 \times 12$ inch remnant corner from the initial cutting. Light gauge wire is used as a hinge and latch for the door. A second Museum Special snap trap is added to the top door (Fig. 1C), which accelerates the closing of the top door and provides enough tension to prevent a captured bird from escaping. 


\section{SETTING}

Each trap site is prebaited with suet for a one week period prior to the initiation of the trap to the area. The trap is attached (with nails) to the tree at a height of six feet and is prebaited in an open position for several days before active setting.

The trap is set by cocking the inverted Museum Special and hooking the notch of the L-shaped wire of the top door on the bail of the Museum Special. Adjustment of the wood screw under the trigger mechanism reduces the movement necessary for tripping. The bird backs down the trunk of the tree and the trigger mechanism is tripped when the bird feeds on the suet resting on the top of the trigger plate.

\section{RESULTS}

A total of 37 birds were captured in 43 active sets ( 86 percent trap success) near Hays, Kansas, during the period of January 31, 1974 to February 24, 1974. Birds captured were eight Downy Woodpeckers, five Hairy Woodpeckers, two Red-bellied Woodpeckers, eleven White-breasted Nuthatches, three Red-breasted Nuthatches, three Black-capped Chickadees, and five Starlings. Six sets of the trap resulted in no captures; one attributed to an escape by a Starling, one tripped by a squirrel, and four assumed to be tripped by wind action. Only one injury to a bird was recorded. A Starling was captured and suffered a broken leg. This injury was believed to be the result of undue excitement caused by a house cat.

This trap works successfully for birds which attend a baited station, but should be checked frequently to prevent overexposure of captured birds and to reduce problems which may be caused by predatory animals.

We wish to acknowledge Dr. Jerry R. Choate, Fort Hays Kansas State College, for critically reviewing the manusceipt and Dr. Charles Ely, Fort Hays Kansas State College, for his assistance and supervision of banding captured birds. 


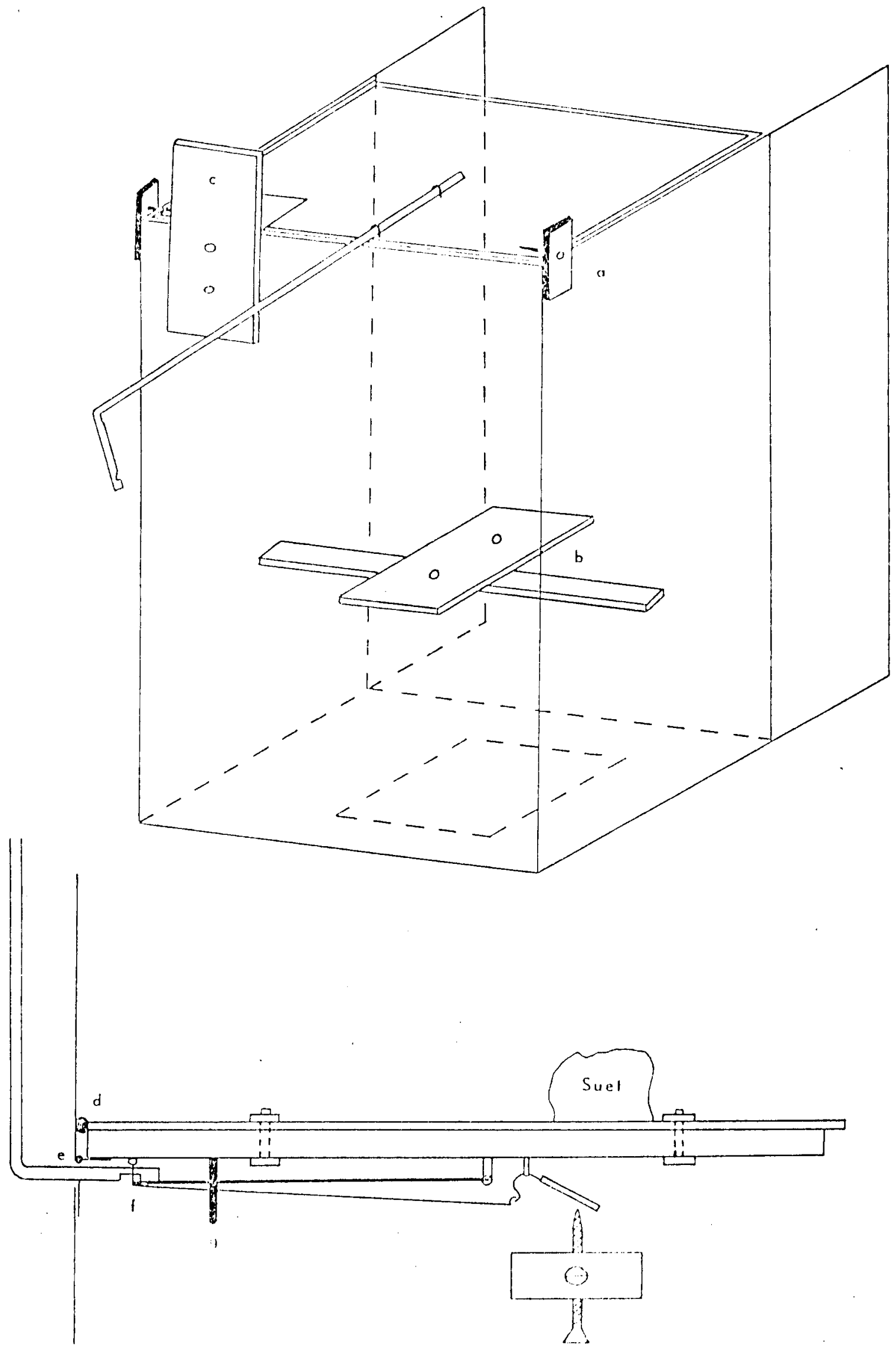

Figure 1. Schematic diagram of the completed trap and trigrol mochanism. 